\title{
PRAVEDAN GRAD, SMISLEN POSAO I SMISLENA DOKOLICA ${ }^{1}$
}

\author{
Nebojša Zelič \\ Sveučilište u Rijeci \\ Filozofski fakultet
}

\begin{abstract}
SAŽETAK
U ovom radu bavim se argumentom za promjenu gradskih politika koje bi omogućile pristup smislenoj dokolici svim građanima, posebno onima koji se nalaze u najnepovoljnijem položaju. Kao najnepovoljnije stojeći pripadnici društva u kontekstu ovog rada određeni su oni pojedinci koji imaju nizak dohodak i poslove koji nisu kreativni, te otežanu mogućnost kreativne stimulacije i u domeni izvan radnog mjesta. Argumenti za kreativan/smislen posao, koji proizlaze iz teorija Johna Rawlsa i Marthe Nussbaum, mogu poslužiti i kao argumenti za kreativnu/smislenu dokolicu. Pri tome, gradovi imaju veću slobodu u promicanju određenog načina života nego što to imaju države. U radu se argumentira da gradske politike trebaju promicati barem smislenu dokolicu budući da mogućnost smislenog posla ovisi velikim dijelom o osnovnoj strukturi cijelog društva.
\end{abstract}

KLJUČNE RIJEČI: smislen posao, dokolica, Rawls, Nussbaum, pravednost, grad

Gradovi su epicentri kreativnosti. ${ }^{2} \mathrm{U}$ njima dolazi do mobilizacije, koncentracije i usmjeravanja ljudske kreativnosti. Posebno je to vidljivo u dva aspekta - poslovima koje gradovi nude i mogućnostima za provođenje dokolice. Prvi aspekt vezan je izravno uz ekonomsku proizvodnju, dok je drugi uz ekonomsku proizvodnju vezan neizravno, odnosno aktivnosti kojima ispunjavamo dokolicu mogu rezultirati novim proizvodima koje onda možemo distribuirati ili staviti na tržište. No, to nije primarna namjera dokolice. U ovom tekstu bavit ću se pitanjem na koji način određene postavke liberalne teorije - konkretnije teorija primarnih dobara i

1 Ovaj rad je izrađen u sklopu projekta „Dobrobit, pripadnost i društvena pravednost“ (UIP2017-05-3462), koji je sufinancirala Hrvatska zaklada za znanost.

2 Prva verzija ovog rada izložena je na konferenciji "Philosophy and Architecture: Social Inequalities and Cities" na IUC-u u Dubrovniku, 2017. godine. Zahvaljujem se svim sudionicima konferencije, posebno Avneru de-Shalitu na sugestijama. 
POLITIČKE PERSPEKTIVE

ČLANCI I STUDIJE

teorija sposobnosti - mogu zahtijevati pristup gradskih politika usmjerenih ka jednakim mogućnostima u provođenju dokolice, to jest aktivnostima koje ljudi obavljaju izvan svog radnog mjesta.

O odnosu grada i kreativnosti oslanjam se prvenstveno na uvide sociologa Richarda Floride, koji je istaknuo promjene u gradovima vezane uz kreativnost (Florida 2005). Prvo, dolazi do zamjena starih industrija kreativnim i visokotehnološkim industrijama. Drugo, ne dolazi samo do zamjene starih industrija, već je kreativni sektor eksplodirao (umjetnost, dizajn, istraživanje i razvoj i općenito profesije temeljene na znanju). Treće, dolazi do određene vrste natjecanja među gradovima u privlačenju kreativnih i talentiranih osoba. Prema tome, jasno je na koji način gradovi stvaraju nova radna mjesta i kako pružaju priliku za kreativna radna mjesta. Mnogi znanstvenici, umjetnici i radnici u kreativnim industrijama dolaze u gradove zbog radnih mjesta koja se u gradovima nude.

No, također je važan i drugi aspekt koji smo naveli. Gradovi nude različite mogućnosti i za aktivnosti izvan radnog mjesta, tj. aktivnosti koje spadaju u dokolicu. Kada kažem aktivnosti onda uistinu mislim na aktivnosti, na određene radnje koje nisu puko odmaranje od rada kao posla ili, bolje rečeno, onoga rada koji je uključen u ekonomsku proizvodnju i za koji smo plaćeni. Ovako shvaćena dokolica nije u suprotnosti s radom, kao što je to odmaranje od rada, već je u suprotnosti s poslom. Kako bi istaknuo Gorz, „rad se čini, a posao se ima“ (Gorz 1999, 131). Dokolica tako uključuje aktivnosti koje su spontane i donose veselje. To uključuje razne rekreativne aktivnosti, uživanje u prirodi, sportske aktivnosti, razne vrste hobija, razvijanje interesa i talenata, zabava i igra, i razne vrste neformalnog obrazovanja. Dakle, ne samo uživanje u aktivnostima kao gledatelj ili konzument već i aktivno djelovanje u provođenju aktivnosti. Rječnikom teatrologa Augusta Boala, stvara se posebna funkcija promatrača i izvođača, gdje promatrač/spectator i izvođač/actor postaju jedno - spectactor (Boal, 1973).

Ovakav razvoj gradova ima pozitivne i negativne učinke na grad kao takav, ali i na ekonomsku i socijalnu (ne)jednakost u gradovima. Okretanje ka kreativnim industrijama, informatičkim tehnologijama i malim start-up tvrtkama sigurno je više u skladu s održivim razvojem i općenito ekologijom nego što je slučaj s tradicionalnim industrijama. Iako su velike industrije masovno nudile radna mjesta, nove industrije puno manje zagađuju i imaju manje nepovoljne negativne eksternalije po okoliš. Povijest je pokazala da se industrije moraju mijenjati da bi mogle očuvati okoliš. Jared Diamond to lijepo ilustrira na primjeru ekološkog sloma Uskršnjih otoka: „Čemu uništiti šumu koja je žiteljima Uskršnjeg otoka trebala za materijalni i duhovni opstanak? To je doista ključno pitanje koje muči svakoga tko razmišlja o uništavanju okoliša koje bi počinili sami stanovnici. Često 


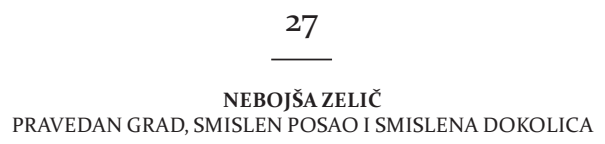

se pitam: 'Što je onaj otočanin koji je posjekao posljednje palmino stablo na Uskršnjem otoku rekao dok ga je sjekao?' Je li, poput modernih drvosječa, uzvikivao: 'Radna mjesta, a ne drveće!' Ili: 'Tehnologija će riješiti naše probleme, ne bojte se, pronaći ćemo zamjenu za drvo!' Ili: 'Nemamo dokaz da palmi nema i drugdje na otoku, trebamo više istraživati, vaš prijedlog o zabrani sječe stabala je preuranjen i samo želite sijati strah!"“ (Diamond 2008, 136-137)

Drugo, u pokušajima privlačenja talentiranih i kreativnih osoba gradovi postaju raznolikiji i tolerantniji. Florida, na primjer, pokazuje kako su gradovi koji privlače takve osobe bolje pozicionirani na onome što on zove bohemian index (broj umjetnika, muzičara i sličnih zanimanja na određenom prostoru) i gay index (broj homoseksualnih domaćinstava na određenom prostoru). ${ }^{3}$ Također, ti su gradovi više prijateljski naklonjeni prema obiteljima s djecom, otvoreni imigrantima i skloniji rasnoj integraciji (Florida 2005, 21).

Treće, „kreativni“ zaokret doprinosi i ekonomskom rastu gradova i stvaranju resursa koji se mogu potom koristiti za kvalitetu javnih službi, javnih dobara i projekata koji povećavaju kvalitetu života građana, a ne mogu biti profitabilni u tržišnim okvirima.

No, unatoč ovim dobrim stranama stvaranju kreativne klase u gradovima, postoje i zabrinjavajuće loši učinci takvog razvoja. Florida tako navodi sljedeće probleme: povećanje nejednakosti u prihodu, što se najviše vidi u gradovima koji su centri kreativnosti; povećanje troškova života; gentrifikacija; politička polarizacija uzrokovana klasnom podjelom (Florida 2005, pogl. 9).

Tome još možemo dodati i to da će san digitalne bohemie, start-up tvrtke i kreativna zaposlenja ostaviti mnoge u neispunjavajućim poslovima u, na primjer, pozivnim centrima, velikim distributivnim skladištima, kurirskim službama, čiji će rad biti vrlo repetitivan, intelektualno nestimulativan i strogo nadgledan. Također, nestanak tradicionalno velikih kompanija znači i nedostatak sigurnosti, povećanje mentalnog i emocionalnog stresa, stvaranje fleksibilnog rada koji ne doprinosi većoj količini slobodnog vremena nego upravo suprotno. ${ }^{4}$ Kao što je i sam Florida istaknuo: „Pravi su gubitnici, u kontekstu prekomjernog rada, oni koji da bi mogli prehraniti obitelj imaju dva posla u punom radnom vremenu s minimalnim plaćama... (Oni) su moderni ekvivalent pregorenih tvorničkih radnika iz devetnaestog stoljeća" (Florida 2005, 23). Dakle, temeljni je problem u tome što nestanak starih industrija i stvaranje novih stvara

3 Florida 2005, pogl. 5 i 6.

4 O tome više vidi u Gorz 1999 i Standing 2011. 
dobitnike i gubitnike. Pri tome, gubitnici su sada u nepovoljnijem položaju nego što su bili ranije.

Taj odnos se vidi i u domeni koja je često bila izvan dosega suvremenih razmatranja o pravednosti, a to je domena dokolice. Ljudi koji imaju bolje poslove i više prihode uobičajeno imaju šire društvene mreže kroz razna udruženja kojima pripadaju i u kojima provode vrijeme izvan posla, to jest radnog vremena. Dokolica, odnosno aktivnosti koje činimo u dokolici mogu stvoriti razlike u društvenom statusu i učiniti ih vrlo primjetnim jednako kao i narav posla koji obavljamo u radnom vremenu ekonomske proizvodnje.

\section{GRUPIRANJE NEPOVOLJNOSTI}

Problem o kojem govorimo su Wolff i de-Shalit nazvali grupiranje nepovoljnosti (Wolff and de-Shalit 2007). ${ }^{5}$ Naime, određeni faktori koji nam služe da bismo mogli odrediti kategoriju onih osoba koje su u (naj)nepovoljnijem položaju imaju tendenciju grupiranja kod određene skupine. U slučaju o kojemu ovdje govorimo, ista skupina osoba ima i posao i dohodak takav da ih postavlja u socio-ekonomski nepovoljniji položaj u odnosu na druge, ali jednako je tako i aktivnosti u dokolici stavljaju u ne toliko ekonomski, ali svakako društveno nepovoljniji položaj.

Slijedeći de-Shalita i Wolffa, možemo reći da cilj društva jednakih ne predstavlja izjednačavanje ljudi po pitanju nekog dobra koje se ima jednako raspodijeliti, kao što je slučaj s poznatom i vrlo utjecajnom raspravom o moneti jednakosti, već da je važno de-grupirati nepovoljnosti, odnosno izbjeći situaciju u kojoj se nepovoljnosti grupiraju unutar jedne skupine. U kontekstu ove rasprave potrebno je dakle de-grupirati nepovoljnosti koje se odnose na lošu narav posla koji se obavlja (monotonost, repetitivnost, fizički napor), mali dohodak i nepovoljnost u dokoličarskim aktivnostima. Naravno, prva stvar koja se pojavljuje u takvim razmišljanjima jest još od Marxa prisutno nadilaženje podjele rada na puko izvršavanje, s jedne strane, i konceptualizaciju, s druge. Idealna situacija je ona u kojoj narav posla svake osobe odgovara ideji radnika kao bića koje posjeduje razum, imaginaciju i kreativnost. No, kao što smo ranije vidjeli, takvo što se vjerojatno neće dogoditi u bliskoj budućnosti. Perspektive umjetne inteligencije pružaju jasnu nadu da će mnoge jednostavne i monotone poslove preuzeti (barem u razvijenim zemljama) roboti, ali ta perspektiva predstavlja nove probleme velikog broja nezaposlenih i čini se da će rješenje tog problema biti dano u odgovoru na pitanje - tko će biti vlasnik robota? Iz ovoga je vidljivo da je pitanje smislenog posla usko vezano uz vlasničke odnose i 
da će potpuni odgovor na taj problem zahtijevati puno dublje promjene u osnovnoj strukturi društva. Ta rasprava nadilazi okvire ovog teksta.

Ovdje je pitanje kako de-grupirati posao i dokolicu lišenu kreativnosti kao jednu karakteristiku društvenog statusa i mali dohodak, ali unutar okvira politika koje lokalna, odnosno gradska vlast može sprovesti u bliskoj budućnosti, a da se ne čeka idealno rješenje. Uvjerenje kako je moguće poboljšati stvari samo radikalnom promjenom može nas učiniti ciničnim prema nekim poboljšanjima koja nisu idealna, ali ipak doprinose boljem životu određenih skupina. U tom slučaju, čini se da su preostala rješenja sljedeća. Prvo je da se određeni poslovi koji su svojim sadržajem problematični više plate. Na taj način osobe s nepovoljnijim poslovima imaju bolji dohodak koji im, između ostalog, omogućuje veći izbor dokoličarskih aktivnosti. U ovom se slučaju ništa bitno ne mijenja u politikama već se samo povećava dohodak za određena zanimanja, što inače nije slučaj. Drugo rješenje odnosi se na sam posao, odnosno na radno vrijeme. Cilj je da određeni poslovi budu jednako plaćeni kao i do sada, ali da se prepolovi radno vrijeme s, na primjer, osam sati na četiri sata. Na taj bi način radnicima na takvim poslovima ostalo više vremena za razvijanje svojih talenata, interesa i kreativnosti u slobodno vrijeme, a dodatni pozitivan aspekt je što bi se i moglo zaposliti više osoba. Naravno, kao i kod prethodnog rješenja, ove su politike prvenstveno vezane uz poslove koji su u domeni gradskih ili lokalnih tvrtki. Okrećemo se pitanju mogu li politike zahvatiti sve građane na takvim zanimanjima, a ne samo one koji su zaposleni u gradskim službama? Jedan od mogućih odgovora može upravo biti fokusiranje na politike koje pružaju više mogućnosti za kreativne aktivnosti u dokolici, dakle izvan radnog mjesta.

Ponovimo opet problem oko grupiranja nepovoljnosti. Dokoličarske aktivnosti često su na tržištu i neke od njih postaju skupe i time nedostupne određenom broju građana; dostupnost tih aktivnosti vezana je uz dohodak koji je često vezan uz dobra zanimanja koja uključuju određeni aspekt kreativnosti; ljudi na takvim poslovima su često bolje obrazovani i imaju razvijene navike i vještine u razvijanju svojih interesa i talenata; također, preko tih aktivnosti su uključeni u šire društvene mreže. Pitanje kojemu se okrećem jest možemo li ponuditi teorijsko objašnjenje zašto bi se pravedne politike trebale baviti mogućnostima koje ljudi imaju u svojoj dokolici? No, zahvaćanje tog problema treba krenuti od važnosti smislenog posla u ekonomskoj proizvodnji i potom vidjeti na koji se način argumenti za smisleni posao mogu koristiti kao argumenti za smislenu dokolicu.

\section{SMISLENI POSAO}

U raspravi o smislenom poslu usredotočit ću se na dvije utjecajne liberalne teorije pravednosti - na Rawlsovu ideju primarnih dobara i na ideju 
POLITIČKE PERSPEKTIVE

ČLANCI I STUDIJE

osnovnih ljudskih sposobnosti Marthe Nussbaum. Iako se ta dva aspekta - primarna dobra i sposobnosti - često shvaćaju kao suparnički prijedlozi, u pitanju smislenog rada (kao i u nizu drugih problema), čini mi se da konvergiraju k istom zaključku. Rad koji izvršavamo na našim poslovima, za razliku od rada koji izvršavamo u dokolici, obvezan je i ekstenzivan i iz tog razloga duboko utječe na naše živote. Također, taj je rad za mnoge primarni izvor prihoda kako bi se mogle obavljati ostale aktivnosti te se često smatra glavnim našim doprinosom u društvenoj kooperaciji. No, ni u kojem slučaju to nije jedini aspekt naših života i u raspravama o pravednosti ne bismo se trebali isključivo usredotočiti na taj aspekt naših života. Ukoliko su primarna dobra ili temeljne sposobnosti osnovni elementi teorije pravednosti onda moramo imati na umu da se oni mogu realizirati i u domeni izvan ekonomske proizvodnje i mogućnosti tog ostvarenja se također mogu smatrati zahtjevima pravednosti. Također, u kontekstu u kojem raspravljamo - nejednakost u gradu - to je nešto što može biti realizirano unutar domene gradskih politika (čak i ukoliko su uvjeti ekonomske proizvodnje dio šire osnovne strukture društva). Nadalje, takve politike osim samog razvoja pojedinaca mogu imati pozitivne učinke na integraciju marginaliziranih grupa i razvoj građanskog povjerenja.

U Rawlsovoj teoriji pitanje pravednosti u ekonomskoj proizvodnji ne odnosi se samo na pitanje dohotka za obavljeni rad, već i na narav posla koji se obavlja. U Teoriji pravednosti Rawls će napisati sljedeće: „Ono što ljudi žele je smisleni posao u slobodnom udruživanju s drugima (...) Da bi se to postiglo nije nužno veliko bogatstvo. U stvari, nakon neke točke vjerojatnije je da će ono biti pozitivno ometanje, u najmanju ruku besmisleno odvraćanje pažnje ako već ne i iskušenje za isprazna ugađanja“ (Rawls 1999, 257-258). Ovo bismo mogli shvatiti ili kao deskriptivnu tvrdnju o ljudskoj psihologiji ili kao normativnu tvrdnju o vrijednim ciljevima u životu. Skloniji sam ovu tvrdnju tumačiti u drugom smislu, dakle bliže perfekcionističkoj interpretaciji, kao što ćemo vidjeti dalje u tekstu. No, čak i da je interpretiramo kao deskriptivnu tvrdnju, sociolozi Florida i Gates potvrđuju da kreativni radnici, dakle oni koji zbog svojih vještina imaju prilike birati mjesto zaposlenja, ne odabiru mjesto zaposlenja isključivo zbog visine dohotka već i zbog sadržaja posla i prihvaćanja raznolikosti u mjestu zaposlenja (Florida 2005, 129).

Prije no što krenemo dalje glavno pitanje glasi - što je smisleni posao? Najlakše ga je definirati negativno. Dakle, kao suprotnost monotonim i rutinskim zanimanjima, kao suprotnost dosadnom i repetitivnom radu. U pozitivnom smislu mogli bismo reći da je to posao koji je svojim sadržajem kompleksan i raznolik, a da u upravljačkom smislu daje određenu moć odlučivanja radniku. Sadržaj se odnosi na korištenje prosudbe, inicijative, intelekta ili talenta, dok se upravljanje referira na moć donošenja 
odluka kako će se rad obaviti. Upravljanje, u stvari, označava zaštitu protiv arbitrarnog uplitanja, s jedne, i servilne ovisnosti, s druge strane. ${ }^{6}$

Ovi aspekti smislenog posla - sadržaj i upravljanje - usko su vezani uz određena primarna dobra za koja Rawls smatra da ih svaka osoba treba da bi mogla ostvariti svoj životni plan neovisno o bilo kojoj obuhvatnoj moralnoj ili religijskoj doktrini koju prihvaća. Načela pravednosti u pluralnoj zajednici imaju dakle funkciju pravedno distribuirati upravo primarna dobra. Primarna dobra koja ovdje imamo na umu su društvene osnove samopoštovanja (u daljnjem tekstu ću na to referirati kao na samopoštovanje) i položaji odgovornosti u političkim i ekonomskim institucijama osnovne strukture društva (položaji). ${ }^{7}$

Samopoštovanje je, po Rawlsovim riječima, „uvjerenje da je nečija koncepcija dobra vrijedna slijeđenja; pouzdanje u sposobnost da će osoba ostvariti svoje namjere dok je to u granicama moći te osobe (...) i da su aktivnosti koje osoba smatra racionalnim javno potvrđene od strane drugih" (Rawls 1999, 440-441). Pri tome je važno imati na umu da treba razlikovati samopoštovanje kao psihološko stanje osobe od društvenih uvjeta za koje možemo očekivati da su povoljne za takvo psihološko stanje. Društvene osnove samopoštovanja su, dakle, „oni aspekti osnovnih institucija koje je uobičajeno smatrati esencijalnima da bi građani imali živi smisao svoje vrijednosti kao moralne osobe“ (Rawls 1999, 256). ${ }^{8}$ Prema tome, moguće je da osoba ima snažnu psihološku karakteristiku samopoštovanja ili samopouzdanja iako nisu ispunjeni uvjeti društvene osnove samopoštovanja, kao što je moguće i obrnuto. Moguće je da neka osoba živi u rasističkom društvu, a da ima snažan osjećaj samopoštovanja. Izvori tog osjećaja mogu proizaći iz karaktera osobe, odgoja, lokalne zajednice ili vjere, ali i dalje smo u pravu kada tvrdimo da u takvom društvu ne postoje društvene osnove samopoštovanja. Možemo reći da samopoštovanje uključuje barem tri stvari u kontekstu u kojem ovdje raspravljamo: mogućnost doprinosa zajednici; da je taj doprinos prepoznat od strane drugih; i da doprinose dobrobiti samog djelatnika, to jest da ne doprinosimo samo pod tuđim uvjetima doprinosa, već da smo u mogućnosti pregovarati naš doprinos. U kontekstu ove rasprave važno je uvidjeti odnos između samopoštovanja i posla. Posao koji obavljamo za dohodak je važan doprinos

6 Ovi aspekti smislenog posla posebno se ističu u Hsieh 2012.

7 Ostala primarna dobra su: osnovna prava i slobode; sloboda kretanja i slobodan izbor zanimanja na osnovi različitih mogućnosti; prihod i bogatstvo. Važnost primarnih dobara samopoštovanja i položaja za smislen posao detaljno je obrađeno u članku Jeffreya Moriartyja, na koji se ja snažno oslanjam u ovom radu. Moriarty 2009.

8 Važno je ovdje napomenuti i ono što Moriarty ističe u gorenavedenom članku, a to je da ti uvjeti nisu nužni da bi osoba imala samopoštovanje već da su determinante samopoštovanja. Ilustracija može biti pušenje i plućna oboljenja, nije nužno da će pušači dobiti određena oboljenja, ali pušenje je determinanta određenih plućnih bolesti. Moriarty 2009, 443. 
POLITIČKE PERSPEKTIVE

ČLANCI I STUDIJE

zajednici i njegova narav može, dakle, bitno utjecati na naše samopoštovanje. Moriarty donosi čitav niz empirijskih istraživanja koja ukazuju na utjecaj statusa i naravi posla na samopouzdanje osobe (Moriarty 2009, 457). Uglavnom, rezultat je da loš status posla i njegova monotona narav bitno utječu na negativan osjećaj samopouzdanja radnika koji taj rad obavljaju.

Također, i drugo primarno dobro - položaji - bitno je određeno poslom koji osobe obavljaju. Za to primarno dobro Rawls kaže da „potiču različite samoupravne i društvene sposobnosti jastva“ (Rawls 2000, 275). Ovo se primarno dobro ostvaruje ovisno o tome koliko ljudima posao dopušta da razvijaju autoritet i odgovornost prema izvršavanju posla. Budući da je posao ekstenzivan i obavezan jasno je da će utjecati u pozitivnom ili negativnom smislu na društvene i samoupravne sposobnosti osobe. Smisleni posao jest dakle onaj koji radnicima pruža ostvarenje određenih primarnih dobara. Ukoliko načela pravednosti trebaju distribuirati primarna dobra onda će to morati uključiti i distribuciju primarnih dobara u odnosu na rad, odnosno u pružanju mogućnosti za smislen posao.

Za razliku od primarnih dobara, teorija sposobnosti Amartye Sena i Marthe Nussbaum ističe da je primarni zahtjev pravednosti kod građana razviti sposobnosti da mogu postići stanja i aktivnosti koje imaju razloga cijeniti. Nussbaum, za razliku od Sena, nudi osnovnu listu ljudskih sposobnosti za koje smatra da ih osnovna struktura društva treba garantirati pojedincima iznad određenog praga. U kontekstu ove rasprave vezane uz smisleni rad, pa onda i uz mogućnost kreativnog provođenja dokolice, spomenut ćemo samo neke od sposobnosti koje Nussbaum ističe. ${ }^{9}$ Kao prvo, sposobnosti koje se odnose na prirodni životni vijek, zdravlje i tjelesni integritet prvenstveno se odnose na opasne poslove. No, budući da govorimo o smislenom poslu potrebno je vidjeti i druge sposobnosti. Svakako je tu sposobnost za imaginaciju i misao (imaginacija). Imaginacija je opisana, između ostalog, kao sposobnost da se na istinski ljudski način, koji je informiran i kultiviran adekvatnim obrazovanjem, koriste zamišljanje, mišljenje i rasuđivanje. To uključuje i sposobnost korištenja imaginacije povezane s našim iskustvom koja se realizira stvaranjem djela koja služe samoizražavanju. Sljedeće dvije sposobnosti su emocije i pripadnost koje, između ostalog, uključuju stanje u kojem naš emocionalni razvoj nije oštećen ili prožet strahom i anksioznosti; te da na poslu budemo sposobni raditi kao ljudsko biće, koristiti praktični razum i ulaziti u smislene odnose uzajamnog prepoznavanja s drugim radnicima. Također, sposobnost kontrole okoline podrazumijeva određenu kontrolu nad svojim radom na

9 Potpuna lista sposobnosti koje Nussbaum navodi su: život; tjelesno zdravlje; tjelesni integritet; osjet, imaginacija i misao; emocije; praktični razum; pripadnost; druge vrste; igra; kontrola svoje okoline. Nussbaum 200o, 78-80. 


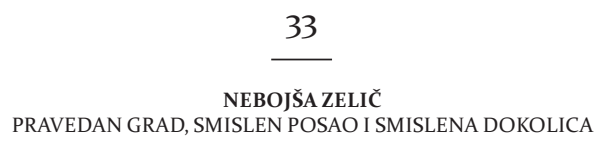

radnom mjestu, slično kao i primarno dobro položaja u Rawlsovoj teoriji. Nussbaum to ne spominje eksplicitno već samo navodi kontrolu nad političkim odlučivanjem, a razlog zbog kojeg to čini je utjecaj koji političko odlučivanje ima na život osobe. No, kao što smo prije napomenuli, snažan utjecaj na život osobe ima i posao koji osoba obavlja, te prema tome iz istog razloga možemo i aspekt upravljanja nad svojim radom podvesti pod sposobnost kontrole svoje okoline.

Dakle, jednako kao i teorija primarnih dobara, i teorija sposobnosti nam pruža dobre razloge da narav i kontrolu nad poslom uključimo u teoriju pravednosti. Možemo reći da primarna dobra i sposobnosti konvergiraju oko pitanja što je smislen posao i da je zahtjev pravednosti osigurati mogućnost smislenog posla svim osobama. Naravno, ovdje se bavim problemom kada nije moguće svima osigurati smislen posao. Ili, što ako je to moguće samo dubinskom promjenom osnovne strukture društva koja se ne čini izglednom u bliskoj budućnosti.

\section{SMISLENA DOKOLICA}

Kao što smo rekli, i teorija primarnih dobara i teorija sposobnosti konvergiraju oko zahtjeva za mogućnošću smislenog posla. No, naravno i između te dvije teorije postoje razlike. Nussbaum je u ranijim radovima kritizirala teoriju primarnih dobara kao prvenstveno usredotočenu na distribuciju dobara kao materijalnih stvari, poput bogatstva i dohotka koja, kao takva, zanemaruje sposobnosti ljudi da ta dobra uistinu realiziraju u radnje i stanja koja imaju razloga vrednovati (Nussbaum, 1990). No, u kasnijim radovima njezina kritika bila je manje stroga. Ona tako kasnije ističe da, uz materijalna dobra, primarna dobra ipak uključuju i sposobnosti građana u njihovoj socijalnoj okolini, kao što je društvena osnova samopoštovanja (Nussbaum 200o, 60). ${ }^{10}$ Ipak, Nussbaum smatra da to nije dovoljno. Ukoliko je Rawls stavio kao primarno dobro društvene osnove samopoštovanja, nije jasno zašto nije stavio društvene osnove zdravlja, imaginacije, odlučnosti i inteligencije." Naravno, to ne znači da je društvo dužno nekome pružiti sve to, to je nemoguće. Ali, jednako kao i sa samopoštovanjem, iako je nemoguće distribuirati samopoštovanje, moguće je odrediti koje su društvene osnove samopoštovanja za koje mislimo da ih je društvo dužno osigurati svakom građaninu.

Ta je kritika važna u kontekstu ove rasprave jer neke od navedenih stvari, kao što su imaginacija i inteligencija, mogu bitno biti društveno

10 No, ipak i na ovom mjestu ističe da su materijalna dobra središnja jer ona definiraju najslabije stojeće.

11 O društvenim uvjetima inteligencije, odnosno o važnosti socijalne pravednosti za pitanje inteligencije videti Barry 2005. 
uvjetovane, a mogućnost za njihov razvoj može biti određen poslom koji obavljamo, ali i aktivnostima kojima se bavimo izvan radnog mjesta.

No, u Rawlsovoj teoriji postoji jedno načelo koje je prilično zanemareno u njegovoj fazi političkog liberalizma, a može poslužiti i kao odgovor na kritike Marthe Nussbaum jer pokazuje da društvene osnove samopoštovanja sadrže puno širu listu nego što je usko shvaćeno samopoštovanje, a jednako tako pruža nam i argument da je za pravednost društvenog uređenja potrebno uključiti i aktivnosti izvan ekonomske proizvodnje. To načelo je Rawls nazvao „aristotelovskim načelom“ (AN).

AN tvrdi sljedeće: „Ako su sve stvari jednake, ljudska bića uživaju u korištenju svojih realiziranih sposobnosti (urođenih ili uvježbanih), i to se uživanje povećava što je sposobnost realiziranija i što je veća kompleksnost aktivnosti“ (Rawls 1999, 374). Važnost tog načela za uređenje društva vidljiva je i u tome što društvene institucije moraju biti orijentirane prema tome načelu jer će inače „ljudska bića svoju kulturu i oblik života smatrati nezanimljivim i ispraznim“, te nadalje „njihov polet i vitalnost će opasti ako im život postane nezanimljiva rutina“ (Rawls 1999, 377). Dakle, uređenje društvenih institucija mora biti usmjereno k tome da ljudi imaju mogućnost realizirati i koristiti svoje sposobnosti.

Vezano uz prije rečeno, AN važno je zato jer se preko njega realizira primarno dobro društvenih osnova samopoštovanja. Rawls će to objasniti na sljedeći način: „Kada aktivnosti ne uspiju zadovoljiti aristotelovsko načelo, vjerojatno će nam izgledati nezanimljive i isprazne, i neće nam pružiti osjećaj kompetentnosti ili osjećaj da su vrijedne provođenja. Osoba je sklona biti sigurnija u svoju vrijednost kada su njezine sposobnosti potpuno realizirane i organizirane na prikladno kompleksan i istančan način“ (Rawls 1999, 386-387). Dakle, društvene osnove samopoštovanja ne mogu se zadovoljiti samo formalnim pružanjem sloboda i jednakih mogućnosti već institucije uistinu moraju biti uređene da pruže uvjete za korištenje svojih sloboda, te da pruže pravičnu jednakost mogućnosti koja će se odnositi i na razvijanje naših talenata i sklonosti u kompleksnim socijalnim aktivnostima.

Iako bi se moglo činiti da je AN načelo izvrsnosti, pogrešno bi ga bilo tako shvatiti. Ono uključuje „veliku raznolikost iskustva“; „užitak u novini i iznenađenjima“; , „inovativnost koju aktivnosti pružaju“; „raznolikost spontanih aktivnosti“; „aktivnosti u kojima uživamo zbog njih samih“; aktivnosti koje činimo „bez poticaja evidentne nagrade“ već je „uključivanje u njih često sama nagrada zbog koje smo činili druge stvari“ (Rawls 1999, 379). U tome kontekstu treba čitati i Rawlsovu opasku o obrazovanju, u kojoj kaže da se resursi za obrazovanje ne bi trebali „raspodijeliti isključivo ili nužno sukladno njihovom povratu predviđenom kroz uvježbavanje sposobnosti vezane uz proizvodnju, već također sukladno njihovoj 


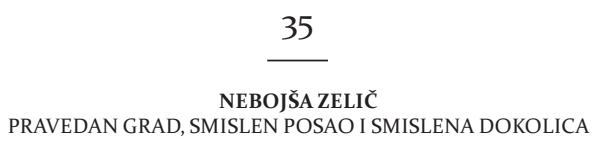

vrijednosti u obogaćivanju osobnog i društvenog života građana" (Rawls 1999, 107). Realiziranje AN, prema tome, uključuje i sposobnosti koje ističe Martha Nussbaum. I kod nje obrazovanje služi za obogaćivanje života pojedinca, a ne samo za stvaranje proizvoda na tržištu rada. Adekvatno obrazovanje za sposobnost imaginacije, kako smo je opisali, ne može biti samo formalno obrazovanje. Iako je ono primarno i nužno, edukacija mora biti dostupna cijeli život kao razvoj svojih interesa i sposobnosti u bilo kojoj životnoj dobi.

AN, kako ga ja shvaćam ovdje, ne govori nam da institucije trebaju stremiti k izvrsnosti osoba u jednoj aktivnosti, već upravo suprotno. Institucije moraju biti organizirane da dopuste multiaktivnost, tako da osobe mogu uistinu otkrivati svoje raznolike talente, interese i sklonosti i uživati realizirajući ih kroz razne aktivnosti s drugima. Ovo načelo u političkoj teoriji artikulira ideju koju u drugim znanostima - sociologiji i pedagogiji - ističu već dugo Richard Florida, Ken Robinson ili Arno Stern, a to je da su ljudi kreativna bića i da im se izražavanje kreativnosti treba omogućiti u svim životnim dobima.

Naravno, AN se može interpretirati kao načelo koje se primarno odnosi na ekonomsku proizvodnju, kao načelo koje prvenstveno, osim obrazovanja, treba urediti uvjete rada na radnom mjestu. Institucije usmjerene prema ostvarenju AN su ekonomske i proizvodne i koje osiguravaju posao na kojemu narav i upravljanje posla osiguravaju primarna dobra samopoštovanja i položaja i jednako tako sposobnosti imaginacije, igre i kontrole. Posao je važan doprinos kooperaciji i većina građana financijski ovisi isključivo o poslu. Iz tog je razloga on obiman, uzima jako puno vremena u našim životima i zato je obavezan, nemoguće ga je izbjeći ili prilagoditi našim drugim obavezama već druge obaveze prilagođavamo njemu. Idealna teorija bi, dakle, trebala ekonomski sustav proizvodnje prilagoditi ANu. Na neki način to i jest Rawlsov cilj. U svom odgovoru Marxovoj kritici liberalizma, točnije kritici da u liberalnoj teoriji uvijek postoji snažna podjela posla koja rezultira otuđenim i besmislenim radom za mnoge, Rawls će napomenuti da će tu podjelu nadići demokracija nad vlasništvom (property-owning democracy), gdje će vlasništvo nad sredstvima za proizvodnju biti široko disperzirano među građanima (Rawls 2007, 321). ${ }^{2}$ Jednako tako i Nussbaum će sposobnost za kontrolom svoje okoline usko vezati uz posjedovanje vlasništva, te time također ići u Rawlsovom smjeru (Nussbaum 2000, 80). No, s ovim rješenjem postoji jednostavan problem,

12 U tom kontekstu treba čitati i Rawlsov prijedlog da se dokolica uključi u primarna dobra (Rawls 1999b, 253). Čini se da on dokolicu vidi samo kao odmor od posla, a da ne referira na sadržaj dokolice. To je shvatljivo jer on uvijek raspravlja u kontekstu dobro uređenog društva koje je uređeno kao demokracija nad vlasništvom ili liberalni socijalizam i gdje je svakome već dana mogućnost smislenog posla. 
 \\ POLITIČKE PERSPEKTIVE}

ČLANCI I STUDIJE

a to je da iako promjena cjelokupnog ekonomskog sustava treba biti važan cilj ona se neće tako skoro dogoditi, a osobe na takvim poslovima će i dalje biti deprivirane u izražavanju svoje kreativnosti.

Činjenica je da smisleni posao nije svima dostupan i, kao što smo na početku naveli, čak i promjenom industrije ne izgleda da će uskoro biti. Florida tako navodi da „samo trećina radnika ima sreću biti novčano kompenzirana za kreativni rad“ (Florida 2005, 117). Rasprave o prekarnom radu također ukazuju na probleme da promijenjene okolnosti čak i u kreativnim zanimanjima stvaraju uvjete nesigurnosti i nestabilnosti koje ispunjenje vezano uz sadržaj posla mogu bitno umanjiti (Standing 2011).

Imamo, dakle, s jedne strane, zahtjev pravednosti, kao što je AN, oko kojeg se slažu i teorija primarnih dobara i teorija sposobnosti, a s druge, trenutnu nemogućnost da se ono realizira kroz ekonomsku proizvodnju. Također, gradovi su posebni prostori u kojima se razlika u smislenim poslovima i razlika u mogućnostima dokoličarskih aktivnosti najjasnije vidi i osjeća te stvara vidljive socijalne nejednakosti. Grupiranje nepovoljnosti najvidljivije je u gradovima i naravno da se to de-grupiranje treba usredotočiti na narav posla i dohodak. No, to će velikim dijelom ovisiti o sveukupnom uređenju osnovne strukture. Neovisno o tome, gradovi su jedinice koje sigurno mogu izravno utjecati na de-grupiranje barem jedne vrste nepovoljnosti, a to je socijalna nejednakost koja se vidi u aktivnostima izvan posla. Također, čak i uz važnost posla kao bitnoga doprinosa kooperaciji, čini se proizvoljnim reći da su važni aspekti ljudskog razvoja koje obuhvaća AN važni samo kada se odvijaju unutar nečijeg rada na poslu od devet do pet.

\section{GRAD I PRAVEDNOST}

Naravno, čim se pravednost veže uz domenu izvan politike ili ekonomske proizvodnje i distribucije odmah nastaje problem kršenja liberalne neutralnosti. Drugim riječima, što će ljudi raditi u svoje slobodno vrijeme nije predmet liberalne teorije pravednosti. Usredotočenje na gradove može riješiti upravo taj problem. Kako ističu de-Shalit i Bell, gradovi imaju svoje posebne ethose koji su drugačiji od država, imaju svoje identitete i nije čudno da promiču različite društvene i političke vrijednosti (Bell and de-Shalit, 2011). Gradovi se mogu i međusobno natjecati u privlačenju građana unutar zajedničke države čiji zakoni i dalje mogu poštovati granice liberalne neutralnosti. Drugim riječima, nije kontroverzno da gradovi mogu javno izražavati određeni način života koji posebno njeguju i s kojim se ponose. Također, nije kontroverzno da se gradovi unutar liberalno neutralnih državnih politika mogu pozivati na dobrobit svojih stanovnika i promicati određeni aspekt dobrobiti koji bi mogao biti kontroverzan kada bi to činile državne institucije. Ukoliko se svako pozivanje na promicanje 
dobrog života kod građana tumači kao perfekcionizam utoliko gradovi unutar svojih jurisdikcija mogu promicati perfekcionističke politike iako su državni zakoni neutralni, odnosno unutar granica javnog uma. Posebno se to odnosi na tumačenje AN i raspodjelu primarnih dobara i sposobnosti koje smo spominjali. Politike koje bi bile u skladu s AN mogu se na primjer optužiti da daju određenim primarnim dobrima prednost u odnosu na ostala, a da to može biti predmet razložnog neslaganja. Na primjer, neke razložne koncepcije mogu vrednovati primarno dobro dohotka puno više nego samopoštovanja i položaja. Ukoliko su ova dva primarna dobra vezana uz mogućnost smislenog posla moguće je da se oni mogu ostvariti samo u ekonomiji koja svakome garantira smisleni posao. Jednako je tako moguće da bi takav ekonomski sustav mogao biti manje ekonomski produktivan, odnosno da bi mogao rezultirati manjim ekonomskim rastom i time smanjenim dohotkom. Na primjer, moguće je da bi firme vođene radničkim samoupravljanjem pravednije realizirale raspodjelu primarnih dobara samopoštovanja i položaja, ali bi smanjile primarno dobro dohotka jer ne bi bile ekonomski produktivne kao kapitalističke firme. Moguće je da u ekonomskom smislu ovo što pišem nije točno, ali nam služi samo kao ilustracija. U tom bi se slučaju neki građani mogli pobuniti da se ne poštuje njihova koncepcija dobra koja dohodak vrednuje više od smislenog rada. Mogli bi reći da država favorizira određenu koncepciju dobrog života nad ostalim i da time neopravdano ulazi u domenu razložnog neslaganja. Mislim da bi se za tu tvrdnju mogao pronaći protuargument koji bi išao $\mathrm{k}$ tome da pravednost unutar ekonomske proizvodnje izmjesti iz domene razložnog neslaganja oko dobrog života. No, to u ovoj raspravi ostavljam po strani. Poenta je ovdje da takav argument, koji bi ponudili ljubitelji visokog dohotka, ne bi doveo u pitanje gradske politike. Kao što je već rečeno, gradovi su slobodniji oblikovati svoje identitete i svoj način življenja i to će neminovno utjecati na favoriziranje određenih načina života. Jednako tako favorizirat će se i određeni načini života koji sigurno spadaju u privatnu sferu izvan ekonomske i političke, a to je sfera aktivnosti u dokolici.

Gradovi imaju slobodu tumačiti AN i različitu vrijednost određenih primarnih dobara. Posebno se to odnosi na realizaciju načela pravedne raspodjele primarnih dobara, kao što je načelo razlike. Rawlsovo načelo razlike tvrdi da su ekonomske i socijalne razlike opravdane ukoliko maksimiziraju položaj najslabije stojećih. To je, dakle, načelo koje daje prioritet onoj skupini koja je određena kao najslabije stojeća. Položaj najslabije stojećih maksimizirat će se raspodjelom što veće količine primarnih dobara. U stvari, gornja rasprava o različitom vrednovanju primarnih dobara unutar pojedinih koncepcija dobrog života usko je vezana uz problem interpretacije načela razlike. Ukoliko ne možemo osigurati podjednako povećanje količine svih primarnih dobara jednako, koja primarna dobra trebamo 
POLITIČKE PERSPEKTIVE

ČLANCI I STUDIJE

uvećati da bismo poboljšali položaj najslabije stojećih? I kao što je već rečeno, manje je kontroverzno kada gradovi prihvate određenu interpretaciju nego državne institucije. Prema tome, grad koji želi biti pravedan i koji želi poštovati načelo razlike može prihvatiti AN kao integralni dio načela razlike. Dakle, poboljšanje položaja najgore stojećih velikim dijelom je poboljšanje njihovih mogućnosti za raznolik život u kojem su im razne aktivnosti dostupne izvan njihovog posla. Aktivnosti u kojima se mogu udruživati s drugima, razvijati svoje interese i upravljati načinom provođenja tih aktivnosti na spontan način. Ljudi mogu kroz te aktivnosti realizirati primarna dobra kao što su samopoštovanje i položaji, te sposobnosti poput imaginacije i kontrole iako im se ta dobra i sposobnosti ne mogu garantirati na njihovom radnom mjestu. Drugim riječima, ako u bliskoj budućnosti ne postoje uvjeti da svi imaju smisleni posao, postoji barem mogućnost da svi imaju smislenu dokolicu. Naravno, ovo bi moglo zvučati kao neko cinično rješenje, i zato je potrebno opet ponoviti da je važno mijenjati uvjete ekonomske proizvodnje. No, mislim da ovaj argument funkcionira čak i kada bismo promijenili uvjete proizvodnje. Čak i u tim poboljšanim uvjetima i dalje može biti problematično zašto bi aktivnosti vezane za određena primarna dobra i sposobnosti bile primarno one na radnom mjestu. Jedan od argumenata može biti da je to zbog doprinosa kooperaciji i njemu se okrećem nakon zaključka o načelu razlike u gradovima.

Ukoliko je dobro da gradovi temelje svoj ekonomski razvoj na industriji i okolini koja privlači talentirane pojedince i kreativnu klasu, tada to može stvoriti velike i jasno vidljive razlike u prihodu i prirodi posla. Poslovi koji imaju karakteristike smislenoga rada - koji su vezani uz samopoštovanje, položaje, imaginaciju i kontrolu okoline - nisu dostupni svima. Jednako tako osobe koje imaju bolje poslove i koji su bolje plaćeni imaju bolje mogućnosti u dokolici razvijati svoje talente, hobije u odnosu na one koji su na slabije plaćenim poslovima. Na taj način ekonomski razvoj gradova dovodi do grupiranja nepovoljnosti. Jedan aspekt de-grupiranja tih nepovoljnosti, kojim se u ovom radu bavim, predstavlja pružanje poticaja, subvencija i mogućnosti za aktivnosti u dokolici koje sadrže karakteristike smislenog rada iako su izvan domene radnog mjesta kao posla. Zbog postojećih ekonomskih razlika to se može prvenstveno osigurati javnim pružanjem službi i dobara nužnih za te aktivnosti. Važno je napomenuti da su aktivnosti o kojima govorim one koje su vezane uz AN, dakle uistinu se govori o aktivnostima koje služe ostvarivanju vlastitih talenata i interesa, a ne bilo kakvo provođenje slobodnog vremena prisutno u primjerima iz filozofske literature, kao što je sjedenje na kauču i jedenje čipsa. AN može biti shvaćeno kao načelo koje ide $\mathrm{k}$ javnom promoviranju određenih načina življenja i, kao što smo već rekli, gradovi mogu provoditi takve perfekcionističke politike. Drugim riječima, u skladu je s načelom 
razlike da ekonomski razvoj koji uzrokuje razlike u prihodima i naravi posla može biti opravdan ukoliko poboljšava standard javnih usluga i javnih dobara koji omogućuju građanima, pogotovo onima u najnepovoljnijem položaju, da osiguraju veću količinu primarnih dobara i sposobnosti izvan ekonomske proizvodnje.

\section{DVIJE KRITIKE}

Okrećem se sada dvjema kritikama koje bi se mogle uputiti argumentu iznesenom u ovom radu. Prva je ta da je cijela rasprava o smislenom poslu problematična jer zahtijeva javnu kategorizaciju smislenog i besmislenog posla. Druga kritika ukazuje na bitnu razliku između ekonomskog rada i rada u dokolici, a to je da ekonomski rad predstavlja bitan doprinos društvenoj kooperaciji, te je pogrešno argumente za smisleni rad koristiti i kao argumente za smislenu dokolicu.

Prvi prigovor kaže da bi javno i političko kategoriziranje moglo rezultirati još snažnijom stigmatizacijom određenih zanimanja i osnaživanju postojećih predrasuda. Vrednovanje nečijeg posla bitan je dio subjektivne evaluacije, ali mi se čini da navedeni aspekti posla - naravi i upravljanje - mogu poslužiti barem kao teorijski standard s kojim možemo započeti. Naravno, često su oni koji pišu o smislenom poslu filozofi i ostali akademici koji intelektualni posao smatraju posebno privlačnim i skloni su sav manualni posao označiti besmislenim, ali to nikako ne mora biti tako. Kao što to pokazuje slučaj Mathewa Crawforda, koji je kao izvrstan student političke filozofije imao ponude raznih think tankova, ali je to odbio zato da bi mogao biti automehaničar, nije uputno kategorizirati poslove na temelju vlastitih preferencija i preferencija okoline u kojoj se nalazimo. ${ }^{33}$ No, iako je to sklizak teren i sivo područje, sigurno ne bismo trebali problem kreativnog rada odbaciti i smatrati nevažnim za političku teoriju i političko djelovanje. No, prigovor se može razviti na sljedeći način. Ukoliko nam je cilj povećati količinu primarnih dobara i razvoj sposobnosti onima koji su u najnepovoljnijem položaju u domeni radnog mjesta utoliko je nužno javno odrediti takvu ciljanu skupinu, čime ne možemo izbjeći problem stigmatizacije i predrasuda. Na ovaj prigovor je teško dati zadovoljavajući odgovor. Dio odgovora je sigurno u tome da bi politike usmjerene k rješavanju tog problema trebale biti univerzalne, a ne usredotočene na određenu skupinu. Univerzalne socijalne politike sprječavaju percepciju drugih kao stigmatiziranih jer su u njih uključeni svi građani, a ne samo neki. Na primjer, osiguranje više javnih prostora na kojima se aktivnosti mogu provoditi, osiguranje lakšeg pristupa tim prostorima, izbjegavanje homogenosti i poticanje heterogenosti stanovništva u svim aspektima (rasnim, 
klasnim, itd). Subvencije za prostore za rekreaciju i provođenje raznih hobističkih aktivnosti, a ne prepuštanje takozvanoj „industriji dokolice“ i načelu laissez-fairea. Uključivanje građana u gradska planiranja koja će ići k izgradnji manjih susjedskih zajednica, a ne da planiranje grada bude isključiva ingerencija stručnjaka. Uglavnom, da javne službe više idu prema kolektivnoj konzumaciji, a ne usmjerene ka privatizaciji i individualnoj konzumaciji. ${ }^{14}$ Naravno, opasnost je uvijek da će takve politike dati snažnije mogućnosti za društveno umrežavanje onima koji su već u povoljnijem položaju i imaju razvijene navike korištenja tih politika prije nego onima koji su u nepovoljnijem položaju i koji takve navike nemaju. Da bi se ta opasnost izbjegla potrebno je određene navike uključiti u obrazovanje od najranije dobi.

Drugi prigovor kreće od činjenice da rad u vidu posla ima primat nad radom u dokolici jer on doprinosi kooperaciji i proizvodnji dobara koja se imaju distribuirati, dok s radom u dokolici to ne mora biti ili čak i nije slučaj. Prigovor tvrdi da je ta karakteristika posla toliko značajna da se karakteristike smislenog rada na poslu ne mogu ni na koji način poistovjetiti sa smislenim radom u dokolici. Taj je prigovor vrlo moćan i potreban je još jedan rad da se na njega zadovoljavajuće odgovori. Na ovom mjestu možemo ukazati na određeni aspekt kooperacije koji nije nužno vezan uz proizvodnju distributivnih dobara. Društvena kooperacija uključuje i stvaranje dobara koji se ne mogu distribuirati, poput normi povjerenja ili integracije. U tom argumentu moramo izaći iz domene filozofsko-teorijske argumentacije i okrenuti se sociološkoj. Prema nekim podacima, ljudi koji su više obrazovani i imaju veći prihod pokazuju visoku normu društvenog povjerenja. Kako to ističe Rothstein, „društveni 'pobjednici' su ljudi koji iskazuju visok stupanj povjerenja u druge ljude, dok je stvar potpuno suprotna s 'gubitnicima'“ (Rothstein 2005, 94). Jedno od objašnjenja jest da će „osobe koje uživaju veća financijska dobra lakše preživjeti slučajeve izdajničkog ponašanja od strane osoba ili institucija kojima su inicijalno vjerovali“ (Rothstein 2005, 94).

No, važan dio objašnjenja je i kvaliteta dokolice. Ljudi koji imaju šire društvene mreže, koje nalaze interesantnim i ispunjavajućim, percipiraju da zajednica i institucije djeluju ka ostvarivanju njihovog dobra. S druge strane, oni kojima nedostaju takva udruženja sebe vide izvan šire zajednice i ne percipiraju na koji način institucije doprinose njihovoj dobrobiti. Politike inkluzije mogu utjecati na određene društvene vještine ili kompetencije pojedinaca koje im onda mogu pomoći da kooperiraju s onima koji su smješteni izvan njihovih društvenih grupa. U ovom je skupu vještina sigurno važno ono što Yamagishi zove socijalna inteligencija (Yamagishi 


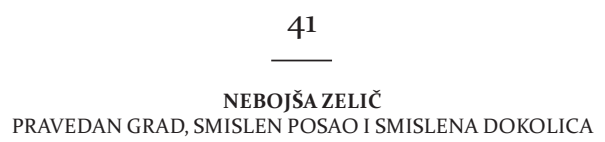

2001). Prema njemu, socijalna inteligencija označava sposobnost da se detektiraju i interpretiraju signali od strane osoba koje susrećemo koji nam pokazuju može li se tim osobama vjerovati. Yamagishi objašnjava da nisko društveno povjerenje i nedostatak socijalne inteligencije stvaraju začarani krug u razvoju osobnosti. Nisko društveno povjerenje je barijera koja sprečava pojedince da ulaze u društvenu interakciju, posebno onu koja uključuje preuzimanje rizika, ali koja može biti plodna. Posljedica toga je podrivanje socijalne inteligencije jer ljude lišava mogućnosti da njeguju tu vještinu u tumačenju signala koji im govore kome mogu vjerovati. $U$ takvoj situaciji osobe neće biti potaknute ući u društvene odnose s onima izvan njihove partikularne grupe prema kojoj je već stvoreno povjerenje. U takvoj izolaciji njihova vještina socijalne inteligencije se ne razvija, što bitno utječe na njihov poticaj za širom društvenom kooperacijom.

Ovime se implicira da ukoliko želimo širu društvenu kooperaciju utoliko moramo stvoriti uvjete koji je omogućuju. Jedan od tih uvjeta, čini mi se, mogu biti politike koje su usmjerene ka široj društvenoj inkluziji kroz aktivnosti u dokolici. Naravno, sljedeći važan aspekt ovakvih politika mora ići k inkluziji kroz raznolike društvene mreže. Ukoliko takve politike uspiju u svom cilju - potaknuti građane različitih društvenih i socijalnih pozadina da provode neformalne aktivnosti zajedno u radu koji je izvan posla, a koji odgovara aristotelovskom načelu - onda mi se prigovor koji tvrdi da je takav rad izvan društvene kooperacije čini pogrešnim. Dakle, iako se problem smislenog rada i dokolice u radu pretežno razmatrao iz normativne vrijednosti pravednog tretmana, ovaj nam sociološki aspekt ukazuje na dodatnu vrijednost smislene dokolice, a to je razvijanje norme povjerenja kroz širu društvenu inkluziju. No, on nije izvan normativne ideje pravednog društva upravo iz tog razloga što stabilnost pravednog društva ovisi o određenom stupnju međusobnog povjerenja i inkluzije.

\section{LITERATURA}

Bell, Daniel and de-Shalit, Avner. 2011. The Spirit of the Cities. Princeton: Princeton University Press.

Crawford, Matthew. 2010. Shop Class as Soulcraft: An Inquiry in the Value of Work. London: Penguin.

Diamond, Jared. 2008. Slom. Zagreb: Algoritam.

Fainstein, Susan. 2010. The Just City. Ithaca: Cornell University Press.

Florida, Richard. 2005. Cities and Creative Class. London: Routledge.

Gorz, Andre. 1999. Reclaiming Work. London: Polity. 
 \\ POLITIČKE PERSPEKTIVE \\ ČLANCI I STUDIJE}

Hsieh, Nien-he. 2012. "Work, Ownership, and Productive Enfranchisement". In Martin O'Neill i Thad Williamson (eds.). Property-Owning Democracy: Rawls and Beyond. Oxford: Blackwell.

Moriarty, Jeffrey. 2009. "Rawls, Self-Respect and the Oportunity for Meaningful Work”. Social Theory and Practice 35(3): 441-459.

Nussbaum, Martha. 20oo. Women and Human Development. Cambridge: Cambridge University Press.

Nussbaum, Martha. 1990. "Aristotelian Social Democracy”. In R. Bruce Douglass, Gerald M. Mara and Henry S. Richardson (eds.). Liberalism and the Good. New York: Routledge.

Rawls, John. 1999a. A Theory of Justice: Revised Edition. Cambridge MA: Harvard Univeristy Press.

Rawls, J. 1999b. “Collected papers”. In Samuel Freeman (ed.). Cambridge MA: Harvard University Press.

Rawls, John. 2007. "Lectures on the History of Political Philosophy". In Samuel Freeman (eds.). Cambridge MA: Harvard University Press.

Rothstein, Bo. 2005. Social Trap and the Problem of Trust. Cambridge: Cambridge University Press.

Standing, Guy. 2011. The Precariat: New Dangerous Class. New York: Bloomsbury.

Wolff, Jonathan and de-Shalit, Avner. 2007. Disadvantage. Oxford: Oxford University Press.

Yamagishi, Toshio. 2001. "Trust as Form of Social Inteligence”. In Karen S. Cook (ed.). Trust in Society. New York: Routledge.

\section{SUMMARY}

\section{The Just City, Creative Work, And Meaningful Leisure}

This paper examines argument for municipal policies designed to provide opportunities for meaningful leisure to all citizens, particularly those who are least advantaged. In the context of this paper the least advantaged citizens are those who have low income, jobs which do not stimulate their creativity, and that face obstacles in developing their creativity outside of their jobs. Arguments for creative/meaningful work given by both John Rawls and Martha Nussbaum can also serve as arguments for creative/meaningful leisure. Also, cities have more autonomy to promote certain way of life than liberal states. This paper argues that city policies should promote at least meaningful leisure since opportunity for meaningful work heavily depends on basic structure of whole society.

KEY wORDS: meaningful work, leisure, Rawls, Nussbaum, justice, city. 